\title{
External kin, economic disparity and minority ethnic group mobilization
}

Article

Accepted Version

Han, E., O'Mahoney, J. and Paik, C. (2014) External kin, economic disparity and minority ethnic group mobilization. Conflict Management and Peace Science, 31 (1). pp. 49-69. ISSN 0738-8942 doi:

https://doi.org/10.1177/0738894213501762 Available at https://centaur.reading.ac.uk/80591/

It is advisable to refer to the publisher's version if you intend to cite from the work. See Guidance on citing.

To link to this article DOI: http://dx.doi.org/10.1177/0738894213501762

Publisher: SAGE Publications

All outputs in CentAUR are protected by Intellectual Property Rights law, including copyright law. Copyright and IPR is retained by the creators or other copyright holders. Terms and conditions for use of this material are defined in the End User Agreement.

\section{www.reading.ac.uk/centaur}

\section{CentAUR}

Central Archive at the University of Reading 
Reading's research outputs online 
External Kin, Economic Disparity, and Minority Ethnic Group Mobilization

\section{Enze Han, Joseph O’Mahoney, and Christopher Paik}

\section{Introduction}

What is the relationship between economic grievance and ethnopolitical conflict? Many theories on ethnic conflict posit a relationship between economic inequality and conflict, and many tend to agree that economic inequality between groups is one of the main causes of grievance and thereby political mobilization (Gurr 1970; Russett 1964). Yet there are disagreements about the exact nature of this relationship (Lichbach 1989). In some situations seemingly economically advantaged groups pursue political mobilization due to resentment of the transfer of wealth to lesser developed groups (Rogowski 1985) or for fear of being exploited by the centralizing state (Hale 2008). But, in other situations it is the poorer groups that are most politically assertive, due to perhaps their economically dominated status (Hechter 1975). This indicates that the relationship between economic wellbeing and group mobilization might be a very complicated one. What researchers need to do is pay attention to the conditionalization of the economic inequality and conflict relationship, and try to figure out specific mechanisms and conditions under which economic inequality leads to conflict (Lichbach 1989, 465). 
Most recent advancements in the literature on civil wars continue to put strong emphasis on the prominent role of economic inequality (Sambanis 2005; Stewart 2008). Indeed, researchers employing the concept of horizontal inequalities have produced a growing array of quantitative work that showcase the crucial role of economic inequality in promoting ethnonationalist conflict (Østby 2008; Østby, Nordås, and Rød 2009; Cederman, Weidmann, and Gleditsch 2011). In particular, Cederman, Weidmann, and Gleditsch (2011) combine newly geocoded data on ethnic groups' settlement areas with spatial wealth estimate, and argue "both rich and poor groups fight more often than those groups whose wealth lies closer to the country average" (478).

This article engages exiting literature on horizontal inequalities, but probes the violent consequences of a different type of economic inequality. In particular, we are interested in the type of ethnic groups that have extensive external kin relations, and how in such conditions the economic disparity between the ethnic group and its external kin group condition the former's grievance construction toward the host state. In such a triadic relationship between an ethnic group, its external kin, and the host state (Weiner 1971; Brubaker 1996), we argue economic grievance of the ethnic group is partly constructed on the basis of a comparative framework involving the group and its external kin. If the ethnic group's external kin enjoys positive economic advantage over the ethnic group, then the latter is more likely to feel deprived and mobilize politically toward the current host state. Thus, our conceptualization is different from previous approaches that focus on domestic inequality between majority and minorities. Rather, we pursue a different setting in which economic equality or inequality is channeled through a comparative framework involving a third actor - the external kin of the ethnic minority group. 
This proposition has strong theoretical ground in the social psychology literature on social comparison (Suls and Miller 1977; Suls and Wills 1991; Suls and Wheeler 2000; Masters and Smith 1987; Stapel and Blanton 2006). Particularly, we argue this propensity for an ethnic group to compare with its external kin is due to the assumed group attributes and psychological closeness. Such a statement is based on the "similarity hypothesis" proposed by Leon Festinger (1954), which contends that comparisons often occur with people that are similar. Therefore, rather than comparing with the different domestic other, it is likely that an ethnic group would think that comparison with its external kin, with which the group shares common or similar cultural backgrounds, is the most meaningful and politically salient.

This proposition is also partly informed by empirical evidence of ethnic conflict behavior around the world. One good example is the Uighurs in the Xinjiang Autonomous Region in China. For the past three decades, Uighur pro-independence movements have intensified their mobilization with increasingly violent means (Millward 2004; Dillon 2004). Although the Chinese government's policy is much to blame for the grievance of the Uighurs, a different aspect of the Uighurs' agitation is that they continue looking towards other Turkic people in Central Asia and Turkey. They compare themselves with the Turkic people outside of China and lament their relative poverty. Many Uighur people consider "areas outside Xinjiang, former Soviet Central Asia and Turkey in particular, as clean and civilized in contrast to the poor and unclean conditions of [their] homeland" (Roberts 2004, 228). In the Uighurs' case, their conception of economic inequality and their sense of economic grievance are partly constructed by their comparison with their external kin, which provides a possible motive for political 
mobilization. The Malay Muslims in three provinces in Southern Thailand are in a similar situation. Ethnic violence has engulfed the population for the past few years. By March 2008, the violence in southern Thailand had consumed over 3000 lives, and the conflict between the Malay Muslims and the Thai state is still ongoing (Funston 2008, 5). Although political and cultural alienation from the Thai state remain salient (McCargo 2008), another factor that intensifies the Thai Muslims' grievance is their relative poverty in comparison with their external kin in Malaysia (Klanarong 2009). The lack of economic development in Southern Thailand and especially Thai Muslims' sense of loss and neglect when they compare Thailand with their external kin state Malaysia, have contributed to their continuing resistance towards the Thai state. It thus seems that this dynamic of comparison between ethnic minority and their external kin exists. This article probes the generalizability of this dynamic, exploring the extent to which this dynamic might exist in other places.

This article is divided in the following sections. In the first section we review the existing literature on the relationship between economic inequality and ethnic group mobilization, in order to identify the inadequacies in current conceptions of the economic foundations for group action. We then propose to examine a certain type of ethnic groups, those that have extensive external kin relations, and suggest a possible way to conceptualize how these ethnic groups might form their evaluation of their economic wellbeing by comparison with their external kin groups. Here in conjunction with a review of existing explanations for ethnic conflict, we generate our hypotheses for empirical testing. The second section investigates the generalizability of our key hypothesis. We utilize a reconstructed version of the Minority At Risk dataset (MAR), in 
juxtaposition with the Geo-referenced Ethnic Power Relations (GeoEPR) and Geographically based Economic data (G-Econ) to generate a set of group-level tests on the relationship between ethnic group/kin economic disparity and ethnic group political mobilization. The results show strong support for our theoretical hypothesis. The empirical analysis part is followed by a discussion of our findings, their strengths and limitations, and then a conclusion of the broad theoretical contribution of our study.

\section{Economic Inequality and Ethnic Mobilization}

There is a vast literature on the relationship between economic variables and ethnic group political mobilization. One of the classic concepts is relative deprivation, which posits that economic inequality rather than absolute poverty is the main cause for group grievance, and such inequality increase the possibility for violent conflict (Gurr 1970). However, later studies questioned this relationship between economic inequality and political mobilization, and have in general dismissed such group-based grievances as the sufficient causal factors for conflict (Collier \& Hoeffler 2004; Fearon \& Laitin 2003).

Debates about whether economic inequality matters for conflict wages on, and most recently scholars have point out the inappropriateness for previous studies relying overwhelmingly upon individual-level statistical proxies, such as the Gini coefficient, to study group-based conflict behavior (Cederman, Weidmann, and Gleditsch 2011, 480). Instead, calls have been made to specifically focus on group-level inequality, or as Stewart defines as "horizontal inequalities to differentiate them from the normal inequality over the range of individuals" $(2002,3)$. Utilizing new data and research methods, empirical researches operationalizing this concept of horizontal inequalities 
have produced consistent statistical support for the positive relations between groupbased inequalities and group conflict behavior (Østby 2008; Østby, Nordås, and Rød 2009; Cederman, Weidmann, and Gleditsch 2011).

That being said, there is much disagreement about whether economically disadvantaged groups or advantaged groups are more likely to pursue political mobilization. We can posit that economically disadvantaged groups are more likely to feel deprived and develop a strong grievance, facilitating collective action for group mobilization. Michael Hechter, for example, considers the least developed ethnically distinct region as the most likely to pursue a political separatism. Because of their domination and exploitation by the economic and political center, it is only natural for the poor region to rebel against the injustice imposed on them (Hechter 1975). On the other hand, a rich and industrialized region, due to its dependence on interregional trade within a union state, would be the least separatist because they have more to lose from the rupture of economic ties (Hecther \& Levi 1979). Donald Horowitz also argues that poor regions are more disposed for secession, albeit by a different set of logics. Horowitz contends that backward groups in backward regions are the most likely to pursue separatist movements because the educated elites from this group will benefit the most from the creation of a new state, despite the fact that the whole region will suffer if it opts for secession (Horowitz 1981).

On the other hand, we can also think that advantaged groups might initiate mobilization to prevent the possibility of being taken advantage of by the less advantaged ones, especially regarding resource redistribution (Stewart 2000). Henry Hale presents the logic of this argument as being that the reason why the richest ethnic regions are the most 
secessionist is because "they have the most to lose should they be exploited by other groups who control the state" (Hale 2000,32). We can thus imagine, because of the wealth and the relatively advanced level of development in an ethnic region, it is rational for members of this group to be more proud of itself and thus put more salience to its own identity rather than at the union state level. At the same time, fear of exploitation from the center motivates group members to rally behind the secessionist banner. On the other hand, if an ethnic region is poor and heavily dependent upon the center for subsidy, then people of this group are less likely to favor secession (Bartkus 1999, 38).

How can we reconcile these competing yet seemingly contradictory propositions? One possibility is that both rich and poor regions are susceptible to political violence (Toft 2003). Most recently, Cederman, Weidemann, and Gleditsch (2011) reached the same conclusion as they found "both rich and poor groups fight more often than those groups whose wealth lies closer to the country average" (478). Not disputing the validity of such arguments, here we propose a different framework to think about the impact of economic inequality. Economic development and group wellbeing are often embedded in different historical and social conditions. As a result of these contextual differences people might develop divergent interpretations and understandings of their economic interest (Herrera 2005). One common assumption in the civil war literature is that since "civil wars take place within societies, they [researchers] assume as well that the key causes of conflict must also be found within the boundaries of formally independent nation-states" (Cederman, Girardin, and Gleditsch 2009, 404). Due to this reason, the existing literature on horizontal inequalities tends to focus specifically on the economic disparity between ethnic minorities and the majority group within a domestic setting. However, we contend 
that there is no necessity that economic inequality has to be framed in that way. A different type of economic inequality might also exist outside of the conventional domestic setting. This is to examine one type of ethnic group that has extensive kin relations (Weiner 1971; Brubaker 1996). The proposition of the existence of such an economic inequality between an ethnic group and its external kin, as well as the subsequent psychological effect of such comparison on the said ethnic group adds more complexity to the underlying relationship between economic factors and political mobilization (Blattman and Miguel 2010, 18).

Indeed, in the civil war literature, there have already been extensive researches that explore how external kin groups affect ethnic group political mobilization and conflict processes (Gurr 1993; Davis and Moore 1997; Van Houten 1998; Saideman 1997, 2001 \& 2002; Saideman and Ayres 2000; Cetinyan 2002; Jenne 2007; Forsberg 2008). Gleditsch (2007), for example, points out that more trans-boundary ethnic groups in a country increase that country's risk of conflict. Cederman, Girardin and Gleditsch (2009) similarly show that external kin support increase the risk of conflict, although the impact is mainly with minority groups that are relatively large.

Following this line of research on the role of external kin, we argue that the presence of external kin provides an alternative channel to frame the existence of economic inequality. We argue an ethnic minority group pays special attention to the situations of its external kin. In such a triadic relationship the ethnic minority group's perceptions and understandings of group economic interests and its evaluations of its welfare are 
channeled through a comparative framework that involves a comparison between the group and its external kin.

Vital to this model is the notion that ethnic minority groups treat their external kin as a reference category. In his classic work Why Men Rebel, Ted Robert Gurr talks about how relative deprivation contributes to group mobilization for violence. Gurr specifically points out that a certain group's value standards are set against a reference framework that involves some other groups which this group does or is thought to identify with $(1970,24)$. Although Gurr's primary focus is on minority/majority comparison and grievance in a domestic setting, he also notes in passing that similar groups tend to be chosen as the reference group $(1970,106)$.

Indeed, Leon Festinger's "similarity hypothesis" states that people do not compare themselves with random strangers, but "[g]iven a range of possible persons for comparison, someone close to one's own ability or opinion will be chosen for comparison" $(1954,118)$. This "similarity hypothesis" has inspired generations of social psychologists to seek theoretical clarification and empirical validation (Goethals and Darley 1977; Tesser 1988; Meisel and Blumberg 1990; Zagelfka and Brown 2005; Miller, Turnball, and McFarland 1988; Major and Forcey 1985).

This strong theoretical footing in the social psychology literature shows support for why the external kin group tends to be chosen as the reference category by the ethnic minority group. Sharing common or similar cultural backgrounds, an ethnic group's external kin offers the most meaningful comparison candidate because of the assumed similarity in group attributes and psychological closeness. Rather than comparing with the different 
domestic other, a.k.a the majority group, it is likely that an ethnic group would think that comparison with its external kin is the most fitting. Thus, sharing a common ethnic identity with its external kin provides a common psychological framework for group members to make sense of the social reality, because such a framework provides people a "set of personal points of reference that locate the self in the social world" (Hale 2004, 468).

Comparisons with the external kin are not only the most meaningful, but can also exert significant psychological effect on the group that non-similar groups cannot. Particularly if people believe that they cannot achieve the same as their comparable peer, such comparisons would have a negative psychological effect on them (Leach and Smith 2006; Burleson, Leach, and Harrington 2005; Gibbons and McCoy 1991). This psychological effect in turn forms the foundation for the ethnic group's grievance towards the host state and the majority group. Theories of horizontal inequalities generally contend that a group would mobilize against the political center to redress inter-group disparities of wealth, because the dominant group is the one that holds the disproportionate wealth and can therefore redistribute that wealth to redress these disparities. The logic of our argument goes a different way, in that we contend the psychological impact of negative comparison between an ethnic group and its external kin would in a way compel the ethnic group to scapegoat the central state for hampering the group's chance for economic advancement as achieved by their external kin.

We thus argue, if the ethnic minority group perceives that their external kin enjoys better economic conditions than the group, members of this group might develop negative 
appraisals of their lives, become dissatisfied, start to demand more from the state, and have a higher possibility to rebel. On the other hand, if a group realizes their external kin's living conditions are worse than them, then group members are more likely to endure the current hardship, if there is any, and be more content with their situation within the majority-controlled home state than one would otherwise predict. We therefore propose that ethnic minority groups' violent political mobilization towards the host state is correlated with whether their external kin enjoys higher levels of economic development. $^{1}$

\section{Data Introduction and Empirical Strategy}

The key to our analysis is how to measure the economic disparity between ethnic groups and corresponding external kin groups. The hypothesis of interest only posits a difference between the mobilization potential of ethnic groups with kin groups of varying levels of relative economic development. There is no implication for a comparison between ethnic groups with external kin and those without, a separate research topic addressed in other works (i.e. Davis \& Moore 1997; Cederman, Girardin, and Gleditsch 2009). For the purpose of empirical testing of our hypothesis, we utilize the Minority At Risk dataset (MAR) from years 1945 to 2000. MAR tracks 283 politically-active ethnic groups throughout the world from 1945; the classification under which MAR categorizes ethnopolitical, non-state communal groups to have "political significance" is determined

\footnotetext{
${ }^{1}$ This hypothesis posits a correlation between actual levels of economic disparity and mobilization. If the mechanism is playing out in any particular case, then we should see explicit articulations of grievance based on comparisons between the minority group and their external kin. These articulations might be expressed as part of a mobilization strategy by elites or as ground-level sentiment. However, in order to determine if this mechanism is working, we need to engage in detailed discourse analysis of elites' speeches or a detailed field study of the group of interest, which is out of the scope of this paper.
} 
by whether "the group collectively suffers, or benefits from, systematic discriminatory treatment vis-a-vis other groups in a society", and whether "the group is the basis for political mobilization and collective action in defense or promotion of its self-defined interests" (Minority At Risk Project 2009).

While the MAR classification yields a smaller set of ethnic groups than the Ethnic Power Relations (EPR) dataset ${ }^{2}$, MAR identifies external kin relations variable (GC10A) for each ethnic group. EPR on the other hand does not provide information on the kin group or country where the largest kindred group for the ethnic group resides. ${ }^{3}$ This is one main reason why we utilize the MAR instead of EPR. By using the MAR, we limit our analysis at groups with history of discrimination and subsequent mobilization, the implication of which will be discussed later in the article.

We are interested only in ethnic groups that have external kin relations in our analysis. One crucial problem for many previous studies on ethnic group conflict is that grouplevel data are very difficult to obtain. In our case, given the definition of the economic disparity variable as between an ethnic group and its external kin group, using the country-level per capita GDP data will likely lead to serious measurement errors. To overcome this problem, we have to find a way to measure economic development at the group-level. While MAR identifies the main kin group for each ethnic group, it does not provide the group location or economic standing at the group level. We therefore match

\footnotetext{
${ }^{2}$ Compiled by Wimmer, Cederman, and Min (2009), the dataset identifies 722 "politically relevant ethnic groups."

${ }^{3}$ The variable in MAR identifies whether a group has external relations or not is GC10. The coding of the variable is as follows: 1 - The group has no close kindred across an international border; 2 - group has close kindred across a border which does not adjoin its regional base; 3 - group has no close kindred in countries which adjoin its regional base; 4 - The group has close kindred in one country which adjoins its regional base; and 5 - The group has close kindred in more than one country which adjoins its regional base. All ethnic groups with values other than 1 have been included in this analysis.
} 
the groups with kin groups from MAR, with a dataset that can give us a measure of economic development at the group level. That is, we explore a localized approach to investigate the kin group effect using two geo-referenced data sets. The first is a group data set in 1990 from the G-Econ project for geographically based economic data (Nordhaus et al 2006), ${ }^{4}$ and the second is the $\mathrm{GeoEPR}^{5}$ dataset in Geographic Information System (GIS) format (Wucherpfenning et al 2010), providing the bases and settlement patterns of the ethnic groups included in the Ethnic Power Relations dataset. ${ }^{6}$ First, G-Econ provides geo-physically based data set on economic activity at the 1-degree longitude by 1-degree latitude resolution at a global scale. The data calculates the "gross cell product" for each of the $1 \mathrm{X} 1$ degree cells, following the same concept as gross domestic product at the state level. Using gridded population data, the gross cell product (GCP) for each grid cell is calculated as follows:

GCP by grid cell $=($ population by grid cell $) X(G C P /$ population $)$ by grid cell .

The GCP/population is obtained from a variety of data including national, state and county data depending on their availability from each country. Given varying administrative capability of each country, the quality of the data is much better for developed nations with detailed socioeconomic accounts of at disaggregated subnational levels. In the case that a grid cell occupies multiple countries, the gross cell product is the area-weighted sum of the countries' reported output.

\footnotetext{
${ }^{4}$ G-Econ data can be accessible at http://gecon.yale.edu/ See also Cederman et al (2011) for their use of GEcon data. While data for 1995 and 2000 are available, Cederman et al (2011) find that the figures for these years are estimates for updated population figures for the respective years, and contain no independent economic data over the 1990 values.

${ }^{5}$ For an introduction of the GeoEPR dataset, see Wucherpfenning, Weidmann, Girardin, Cederman, and Wimmer (2011).

${ }^{6}$ EPR dataset can be accessible at http://www.icr.ethz.ch/research/epr
} 
On the other hand, GeoEPR geo-references ethnic groups from the EPR dataset. For the purpose of this article, all the ethnic groups included in GeoEPR with identical names as listed in MAR dataset were kept. We then obtained geographic information of the location and spread of this set of ethnic groups, and placed this information on top the GEcon data, which provides at the grid cell level the economic output and population.

Summing all the cells that cover an ethnic group gives the economic output and the total population in the region.

Since this section focuses on the group-level analysis of the kin group effect, the following empirical analysis only includes pairs of groups that have geographic information available. That is, if an ethnic group is matched to its kin group, but there is no information on the kin group from GeoEPR, then the observation is dropped. The resulting number of pairs of ethnic groups and their kin groups, both of which have geophysical location and spread information, is 141 . The following map shows world distribution of ethnic groups included in our analysis.

\section{MAP HERE}

The main variable of interest here is the wealth of a localized ethnic group relative to its kin group. The ratio of wealth is measured as the following:

\section{Ratio of Ethnic Group to Kin Group = Total Gross Product Per Capita by Ethnic Group/ Total Gross Product Per Capita by Kin Group.}

Here the total gross product per capita is obtained by summing the GCP of all the cells occupied by the group, divided by the total group population in all the cells. 
The dependent variable is a binary variable, equal to 0 if there was no reported political mobilization and 1 otherwise from MAR REBEL variable between 1945 and 2000. Since the binary approach may omit potentially important variations in the extent of rebellious activity participated in by a group, we also look at how the mean REBEL variable. This variable ranges in value from 0 to 7 , with 0 as no rebellion reported and 7 as protracted civil war. Using the mean REBEL may change implications drawn from the binary approach, since the motivation behind each increasing level of violent political mobilization (ex. scattered terrorism $(\mathrm{REBEL}=1)$ to large-scale insurgency $(\mathrm{REBEL}=6)$ may significantly differ from deciding to act violently in any form as opposed to peaceful means. $^{7}$

It is necessary to address other potential channels through which ethnic group mobilization may result, and test whether our claim holds controlling for these other factors, so we control a set of variables that are commonly associated with ethnic group mobilization. Existing explanations for ethnic group mobilization can be roughly divided into two main approaches - the first one dealing mainly with group grievance as motivation for mobilization, and the other one with opportunity structures that permits a group to mobilize successfully.

The first set of approaches puts the focus squarely on an ethnic group's grievance as the motivations for mobilization and rebellion. These approaches are thus inspired by the relative deprivation theory as we mentioned previously (e.g. Gurr 1970; Horowitz 1985). Thus, economic differences between the minority group and the majority, a.k.a horizontal

\footnotetext{
${ }^{7}$ The exact coding of the dependent variable is as follows: 0 - none reported; 1 - political banditry, sporadic terrorism; 2 - campaigns of terrorism; 3 - local rebellions; 4 - small-scale guerrilla activity; 5 intermediate guerrilla activity; 6 - large-scale guerrilla activity; and 7 - protracted civil war.
} 
inequalities, are often blamed for leading to the minority group's grievance.

Alternatively, studies have shown consistently that poverty is strongly correlated with ethnic conflict, in the sense that low per capita incomes and slow economic growth are both robustly linked to civil war (Blattman \& Miguel 2010).

This economic discontent would certainly be correlated with any political inequalities between the ethnic minority group and the ruling majority, wherein the minority group suffers political marginalization and lack of access to political power. Political exclusion has been documented as one main contributor for ethnic violent conflict (Wimmer, Cederman, and Min 2009; Cederman, Wimmer, and Min 2010). If an ethnic group is constantly excluded from the political process, this would certainly intensify feelings of alienation and injustice, which then presumably would pave the way for political action. Similarly, an ethnic minority's grievance within the current state can also be dependent on whether the group has historically been autonomous or independent by itself. For a group that historically enjoyed its own freedom, it is presumably more difficult for group members to make sense of the current domination by others, which foments grievance and creates a demand for greater autonomy. Alternatively, autonomous structure might also provide resources for groups to overcome the collective action problem (Cornell 2002).

There are also approaches that look at the cultural variable - that is treating ethnic and cultural diversity as a cause of civil conflict. However, some quantitative analyses of this relationship do not find such a relationship at all (Collier, Hoeffler, and Söderbom 2004; Fearon 2004). Cultural or ethnic differences between the two can make inter-ethnic 
communication difficult, and can lead to alienation of the minority group and lead to a strong sense of non-belonging within the current state. The situation may be especially prone for conflict if there is ethnic polarization involved (Montalvo and Reynal-Querol 2005). Finally, we might also posit that democratic societies are probably more inclusive than authoritarian regimes, and thus are less conflict-prone, although recent studies tend to portray it as a parabolic relationship between regime type and ethnic political mobilization (Elbadawi and Sambanis 2002; Hegre et al. 2001).

The MAR includes several measures of difference between the minority group and the majority group in the same country between 1945 and 2000. We include the timeaveraged composite indices for economic differences (ECDIFXX), political differences (POLDIFXX), and ethnic differences (ETHDIFXX). ${ }^{8}$ Because changes in the location of ethnic groups over time are not captured by GeoEPR data, the following regression results are necessarily pooled over the time period. To measure the effect of country regime types, we also include the mean polity scores for the country where the ethnic group resides. To measure the impact of historical autonomy, we include a dichotomous variable from MAR that indicates whether the group has been historically autonomous (AUTON). Finally, we also control economic development at the group level by using the G-econ data. ${ }^{9}$

Other than these grievance-based variables, we also try to control some factors that provide opportunities and resources for ethnic conflict (e.g. McAdam, Tarrow, and Tilly

\footnotetext{
${ }^{8} \mathrm{We}$ did not use the variables on political and economic discrimination (POLDIS, ECODIS) because these two variables are only for the post 1980 years.

${ }^{9}$ Since we are already controlling group-level economic development, there is no theoretical justification to look at the country-level GDP per capita any more.
} 
2001). One factor that has been noticed by scholars that is supposed to correlate strongly with group mobilization is how much a certain group is geographically concentrated. The argument is that groups that are geographically concentrated enjoy higher levels of political, social and economic self-sufficiency (Jenne, Saideman, and Lowe 2007, 542). Also, it is much easier for such groups to justify their claims for independence based on ethnic homogeneity (Toft 2002). Furthermore, compact groups are presumably more likely to defend themselves.

Other than group concentration, group size is also considered relevant for political mobilization (Buhaug, Cederman, and Rød 2008; Cederman, Girardin, and Gleditsch 2009). Due to the size, large groups are more likely to challenge the central state due to their superior size; and they can also effectively mobilize more resources than smaller groups. In addition, we also believe if an ethnic group's potential for political mobilization should increase with the extent of political access its external kin enjoy. It means if the external kin group have more access to political power, then presumably the potential for it to support the ethnic group for mobilization should also increase.

Therefore, we include in our model three additional variables. GROUPCON is from MAR, which measures group concentration level. GC11 is also from MAR, which measures the extent to which external kin groups have access to political power. Finally, we include the total population of ethnic groups from the G-Econ dataset.

EPR also provides a number of potentially suitable control variables. These include indicators for whether the ethnic group is excluded from power (EXCLUDED), discriminated (DISCRIM), powerless (POWERLESS, STAT) and whether the group has 
autonomy (AUTONOMY, SEPARATIST). The MAR indicators were used in their place since only 21 groups in EPR data (out of a total of 63 that had these variables in EPR) had identified kin groups, compared to a total of 141 groups with MAR indicators. Similarly, an alternative dependent variable would be to assess whether a rebellion was due to ethnic conflict or not. Ethnic Armed Conflict dataset (EAC), based on the Armed Conflict Dataset, provides such categorization (Cederman, Min, and Wimmer 2010). We resort to using the MAR indicator however since EAC's categorization of ethnic conflict only identifies ethnic-driven conflicts at the country level. Since this approach does not target group-level violence, there may only be indirect evidence suggesting that the more ethnically driven conflict there is within a country, the more disparity there appears to be.

\section{Findings}

Table 1 shows summary statistics. 141 ethnic groups from 79 countries are included in the dataset. On average ethnic groups fared better than their kin, as shown by the average economic disparity measure of 1.42 . This indicates that in the dataset, ethnic groups actually have better economic standings than their kin by roughly 40 percent. The variance among the ethnic group and kin pairs is significant. For example, the relative economic standing among Russians living in Tajikistan relative to their kin in Russia is at 0.21, while the relative economic standing among Malaysian Chinese compared to their kin in China is over 7.

The mean rebellion index is close to 1 , suggesting that the majority of political mobilization effort resulted in banditry and sporadic terrorism, rather than civil war and 
large guerilla attacks. In fact, out of 138 observations, about half of the ethnic groups (62) witnessed zero reported incident of political mobilization against the dominant groups. ${ }^{10}$

Table 2 presents results for which the dependent variable is a binary variable, equal to zero if there was no reported political mobilization and one otherwise. Both OLS and probit specification yield similar results. The economic disparity variable has a negative and statistically significant coefficient. Column 4 for example suggests that a unit increase in the ratio between the group per capita gross product and kin per capita gross product is related to a decrease in the likelihood of experiencing political mobilization by 7.8 percent. The negative correlation between the two variables remains significant with inclusion of control variables. The localized ethnic group's GDP per capita also plays a positive but insignificant role.

The results also show that when focusing only on ethnic groups that have identifiable kin groups, factors commonly attributed to political mobilization are not as significant, with the exception of the kin group's access to political power. Given the focus of this empirical exercise, this finding is not surprising. To our knowledge no prior work has focused specifically on the ethnic groups with kin group relations and their grievances against the central state. This finding suggests that, at least within the subset of ethnic groups that have kin groups, their grievance outcomes are much more strongly impacted by kinship factors, rather than domestic ethnopolitical and historical variables. The coefficient value of -0.113 under Colum 6 for example suggests that a unit increase in the access index score is likely to decrease the likelihood of experiencing political

\footnotetext{
${ }^{10}$ Five groups that did witness protracted civil war and thus have 7 as the rebellion index value include Serbs, Croats and Muslims in Bosnia, Serbs in Croatia in 1995, and Armenians living in Azerbaijan during the early 1990s.
} 
mobilization by 13.3 percent. A country's level of economic differentiation, geographic isolation, and a sense of historical autonomy appear to positively influence the likelihood of a political act, although none of them are statistically significant. On the other hand, both ethnic differentiation and democracy levels both have negative coefficient values, suggesting that these factors are negatively correlated with political mobilization.

Using a binary dependent variable may potentially overlook important variations in the intensity level of rebellions outlined in MAR. Furthermore with the binary dependent variable, the political differentiation and absolute wealth of ethnic groups appear to have the opposite effect from what one would expect from the current literature. Table 3 presents results using the mean rebellion index as the dependent variable instead. Given the nature of the data, which contains many zero rebellion observations and is potentially truncated, we present both OLS and Tobit regressions. While the categorical nature of the dependent variable does not yield an easy interpretation of the coefficient value, the findings do confirm the negative correlation that we observe from Table 2. Column 1 suggests that a unit increase in the economic disparity ratio will likely see a decrease in the mean rebellion index by a factor of 0.213 , and the magnitude of the disparity coefficient value increases significantly under the tobit specification. The kin group access variable also remains statistically significant, while domestic sociopolitical variables do not. Under the OLS specification, the overall economic standing of ethnic groups and their total population also appear to have statistically negative correlations with the rebellion index, although the magnitudes are small. Columns 2 and 3 suggest that a thousand dollar increase, about a 20 percent increase from the mean per capita grow product, is likely to decrease the mean rebellion index by 0.031 . 
TABLE 2 and 3 HERE

\section{Sensitivity Analysis}

We have used several different estimation procedures with different specifications of the dependent variable and the main result is consistent across models. The current section considers further tests of the robustness of the above findings. ${ }^{11}$ The economic disparity variable was calculated without reference to the source of the wealth production. One potential issue is how easy it would be to restrict or redistribute economic wealth among members of different ethnic groups, or even a particular sense of grievance arising from the exploitation of natural resources coming from a group's homeland. Income from oil production may involve different dynamics from other types of economic opportunities. The G-Econ data do not allow for differentiating between different sources of wealth. Instead, using Fearon and Laitin's (2003) data we controlled for whether the country in which an ethnic group mainly resides derives at least one-third of its export revenues from fossil fuel. The magnitude, direction and significance of the coefficient of interest were not substantially different when including this measure in our models. Fearon and Laitin also emphasize mountainous terrain, a proxy for whether a group has the potential to retreat to an inaccessible location to hide from government forces. Including their measure of mountainous terrain had little or no effect on the main results.

Another potential concern is whether the ethnic groups are primarily rural or urban. The MAR variable GC119 is a measure of rural/urban distribution. ${ }^{12}$ We used the value

\footnotetext{
${ }^{11}$ Data and code for these tests are available from authors.

12 There are five categories; mainly rural (>80\%), mostly rural (60-80\%), mixed urban/rural, mostly urban $(60-80 \%)$, and mainly urban $(>80 \%)$.
} 
coded for the decade 1990-1999. For the groups included in our data, 33 of them do not have a "basis for judgment", leaving 99 groups with some value on this variable. After controlling for rural/urban distribution, the magnitude and significance of the coefficient on the kin disparity measure are substantially unchanged.

We also controlled for world regions. ${ }^{13}$ Including all region dummies at once in the models with a dummy dependent variable left the magnitude and direction of the coefficient of interest unchanged, and significance still high except in the model in which we also controlled for oil and terrain. This was the same for probit estimation. When using the disaggregated dependent variable and running an OLS on the mean, the coefficient again only loses significance in this model, as it does in the tobit. However, the direction and magnitude of the coefficient are not affected by controlling for world regions, suggesting that the issue is one of insufficient observations or multicollinearity.

Another robustness test we performed was to rerun the models on G-Econ data and MAR rebellion data only from post-Cold War period (1991-2000), since the temporal scope of G-Econ database is limited to 1990 . Under this restriction we found that the direction of the coefficient value and the statistical significance remained robust under the binary approach. The decision to pursue a type of violent rebellion, whether through guerilla attacks or protracted civil wars over this period, was significantly related to the economic disparity level between the ethnic group and the kin in 1990. Similar to the main findings in this paper, the relative economic wealth reduced the likelihood of an ethnic group rebelling against the state. This relationship also remained strong when the dependent

\footnotetext{
${ }^{13}$ We used the MAR variable Region, with values for the Western Democracies and Japan, Eastern Europe and the former Soviet Union, Asia, North Africa and the Middle East, Sub-Saharan Africa, and Latin American and the Caribbean.
} 
variable was the mean REBEL score between 1991 and 2000, although the statistical significance disappeared after controls were added to the regression. The variation in the intensity level increased standard errors in the result. In a closer look, during this period the relative frequency of violent rebellions among MAR groups also increased: out of 955 observations recorded in MAR between 1991 and 2000, only about half (529) incidents involved non-violent demonstrations or symbolic resistance. In contrast, between 1945 and 2000 the majority of incidents (6528 out of 9063) appear to have been peaceful with no report of violence. The overall trend seems to be of less frequent political mobilization but of more violent nature.

\section{Discussion}

Our group-level analyses have shown strong support for our main theoretical hypothesis. These statistical results indicate that there is a correlation between the economic disparity between ethnic groups and their external kin groups and the level of rebellious activity experienced by the ethnic groups. There are two ways of interpreting this finding. The first is in terms of potential generalizability of the mechanism or dynamic we noted in the introduction. As with the cases of the Uighur minority group in western China and the Malay Muslims in southern Thailand, the rhetorical use of kin group comparisons as part of their political mobilization strategies may be a widespread phenomenon. If these material disparities are associated with rebellious activity, then maybe the dynamic is manifesting in numerous cases other than these two cases. The next step for future research is to analyze other cases of minority group political activity to see whether kin 
group comparisons are being used for mobilization purposes. The disparity data can help identify likely or unlikely cases of this.

The second mode of interpretation is that the statistical results establish or suggest an empirical regularity that now stands in need of explanation. Given the non-experimental nature of this research (which is true for most social science), causation cannot be definitively determined. However, one plausible reason why this empirical regularity exists can be seen from our brief discussion of the mobilization mechanism with the Uighurs and Malay Muslisms above. Given that the correlation of interest holds even after controlling for other variables, the regularity cannot be easily explained with reference to other more common dynamics in the literature.

Having said that, we acknowledge that this article has limitations. One concerns the use of the Minority At Risk dataset. As a dataset that focuses on the groups that have already been mobilizing, all other groups that have not been politically active have effectively been excluded from our analysis. GeoEPR also is cross-sectional, with no additional information on the possible movement of these ethnic groups across time. The data analysis in the article therefore is from pooled regression and does not allow for time variation. Thus, our analysis has selected cases on the dependent variable, in that no groups with no political mobilization have been included. However, there is substantial variation in our dependent variable. Selecting cases based on a rule that is correlated with the dependent variable, as this analysis does, can lead to an underestimation of the effect of the independent variables. That means the magnitude of the coefficients might be larger than we estimate (Geddes, 1990). 
Second, it is impossible to tell the direction of the causation simply from looking at our regression results. That is, there is a potential endogeneity problem, meaning that we can think of a plausible causal link between rebellion and economic disparity, whereby rebellion is the cause of the disparity. Without better quality data, or a suitable instrumental variable, this is not an issue that we can address here. Instead, this issue can only be addressed through studying sequencing in case studies.

Finally, we also realize that the relationship between ethnic groups and their external kin should be more interactive and more dynamic than our model on economic differences alone can allow. Other key factors such as external kin support for ethnic group mobilization is not taken into consideration in our analysis, due to the unavailability of data. Future research is needed to combine the two levels of analysis together.

\section{Conclusion}

We started our article with a discussion of the relationship between economic factors and ethnic group mobilization. Participating in the literature on horizontal inequalities and ethnic group political mobilization, we posit instead that we can conceptualize a different type of economic inequality outside of the conventional domestic setting - that is the economic disparity between ethnic groups and their external kin groups. We argue that an ethnic group's perception of their economic wellbeing and subsequently their political grievance, is based upon a comparison between itself and its external kin. Our focus thus offers a fresh angle to explore the impact of economic disparities outside of the domestic dimension. We argue that if the ethnic minority group perceives that its external kin enjoys better living standards, then the group is more likely to feel deprived and thus is 
more likely to mobilize to demand more from the current home state. The results of the statistical tests, controlling for grievance and opportunity variables, have supported the primary hypothesis. That is, when the economic disparity between the ethnic minority group and its external kin increases, the intensity of group mobilization also increases.

Our finding supports the general approach on ethnic mobilization that focuses on external kin relations. In our case, we demonstrate that external kin groups can be crucial reference points for ethnic groups in their evaluations of living standards. These evaluations subsequently provide permissive conditions for group grievance construction and political mobilization. This study indicates that economic inequality can be perceived outside of the domestic setting and calls for future empirical case studies focusing on how this comparative economy framework works out in ethnic groups' preference formation. 


\section{References}

Bartkus, Viva Ona. 1999. The Dynamic of Secession. Cambridge: Cambridge University Press.

Blattman, Christopher, and Edward Miguel. 2010. "Civil War." Journal of Economic Literature no. 48 (1):3-57.

Brubaker, Rogers. 1996. Nationalism Reframed: Nationhood and the National Question in the New Europe. Cambridge; New York: Cambridge University Press.

Buhaug, Halvard, Lars-Erik Cederman, and Jan Ketil Rod. 2008. "Disaggregating EthnoNationalist Civil Wars: A Dyadic Test of Exclusion Theory." International Organization no. 62 (3):531-51.

Burleson, Kathryn P., Colin Wayne Leach, and David M. Harrington. 2005. "Upward Social Comparison and Self-Concept: Inspiration and Inferiority among Art Students in An Advvanced Program." British Journal of Social Psychology no. 44:109-23.

Lars-Erik Cederman, Brian Min, and Andreas Wimmer. 2010. "Ethnic Armed Conflict dataset." http://hdl.handle.net/1902.1/11797 V1 [Version].

Cederman, Lars-Erik, Andreas Wimmer, and Brian Min. 2010. "Why Do Ethnic Groups Rebel? New Data and Analysis." World Politics no. 62 (1):87-119.

Cederman, Lars-Erik, Luc Girardin, and Kristian Skrede Gleditsch. 2009.

"Ethnonationalist Triads: Assessing the Influence of Kin Groups on Civil Wars." World Politics no. 61 (3):403-37.

Cederman, Lars-Erik, Nils B. Weidmann, and Kristian Skrede Gleditsch. 2011. "Horizontal Inequalities and Ethnonationalist Civil War: A Global Comparison." American Political Science Review no. 105 (3):478-95.

Cetinyan, Rupen. 2002. "Ethnic Bargaining in the Shadow of Third-Party Intervention." International Organization no. 56 (3):645-77.

Collier, Paul, and Anke Hoeffler. 1998. "On Economic Causes of Civil War." Oxford Economic Paper no. 50 (4):563-73.

Collier, Paul, and Anke Hoeffler, and Måns Söderbom. 2004. "On the Duration of Civil War." Journal of Peace Research no. 41 (3):253-73.

Cornell, Svante E. 2002. "Autonomy as a Source of Conflict: Caucasian Conflicts in Theoretical Perspective." World Politics no. 54 (2):245-76.

Davis, David R., and Will H. Moore. 1997. "Ethnicity Matters: Transnational Ethnic Alliances and Foreign Policy Behavior." International Studies Quarterly no. 41 (1):171-84.

Dillon, Michael. 2004. Xinjiang - China's Muslim Far Northwest. London and New York: RoutledgeCurzon.

Elbadawi, Ibrahim, and Nicholas Sambanis. 2002. "How Much War Will We See? Estimating the Prevalence of Civil War in 161 Countries, 1960-1999." Journal of Conflict Resolution no. 44 (2):228-49.

Fearon, James D. 2004. "Why do Some Civil Wars Last So Much Longer than Others?" Journal of Peace Research no. 41 (3):275-301.

Fearon, James D., and David D. Laitin. 2003. "Ethnicity, Insurgency, and Civil War." American Political Science Review no. 1:75-90. 
Festinger, Leon. 1954. "A Theory of Social Comparison Processes." Human Relations no. 7:117-40.

Forsberg, Erika. 2008. "Polarization and Ethnic Conflict in a Widened Strategic Setting." Journal of Peace Research no. 45 (2):283-300.

Funston, John. 2008. Southern Thailand: The Dynamics of Conflict. Washington, DC: East-West Center.

Geddes, Barbara. 1990. "How the Cases You Choose Affect the Answers You Get: Selection Bias in Comparative Politics." Political Analysis no. 2 (1):131-50.

Gibbons, Frederick X., and Sue Boney McCoy. 1991. "Self-Esteem, Similarity, and Reacrtions to Active versus Passive Downward Comparison." Journal of Personality and Social Psychology no. 60:414-24.

Gleditsch, Kristian Skrede. 2007. "Transnational Dimensions of Civil War." Journal of Peace Research no. 44 (3):293-309.

Goethals, George R., and John M. Darley. 1977. "Social Comparison Theory: An Attributional Approach." In Social Comparison Processes: Theoretical and Empirical Perspectives, edited by J. M. Suls, and R. L. Miller. Washington, DC: Hemisphere.

Gurr, Ted Robert. 1970. Why Men Rebel. Princeton, NJ: Princeton University Press. . 1993. Minorities at Risk: A Global View of Ethnopolitical Conflicts. Washington, D.C.: United States Institute of Peace Press.

Hale, Henry E. 2000. "The Parade of Sovereignties: Testing Theories of Secession in the Soviet Setting." British Journal of Political Science no. 30 (1):31-56.

—. 2004. "Explaining Ethnicity." Comparative Political Studies no. 37 (4):458-85. . 2008. The Foundations of Ethnic Politics: Separatism of States and Nations in Eurasia and the World. Cambridge; New York: Cambridge University Press.

Hechter, Michael. 1975. Internal Colonialism: The Celtic Fringe in British National Development, 1536-1966. London: Routledge and Kegan Paul.

Hechter, Michael, and Margaret Levi. 1979. "The Comparative Analysis of Ethnoregional Movements." Ethnic and Racial Studies no. 2 (3):260-74.

Hegre, Harvard, Tanja Ellingsen, Scott Gates, and Nils Petter Gleditsch. 2001. "Toward a Democratic Peace? Democracy, Political Change, and Civil War, 1816-1992." American Political Science Review no. 95 (1):33-48.

Herrera, Yoshiko M. 2005. Imagined Economies: The Sources of Russian Regionalism, Cambridge Studies in Comparative Politics. New York: Cambridge University Press.

Horowitz, Donald L. 1981. "Patterns of Ethnic Separatism." Comparative Studies in Society and History no. 23 (2):165-95.

Jenne, Erin K. 2007a. Ethnic Bargaining: The Paradox of Minority Empowerment. Ithaca: Cornell University Press.

Jenne, Erin K., Stephen M. Saideman, and Will Lowe. 2007b. "Separatism as a Bargaining Posture: The Role of Leverage in Minority Radicalization." Journal of Peace Research no. 44 (5):539-58.

Klanarong, Nisakorn. 2009. "Border Crossing of Muslim Women in Southern-border Provinces of Thailand." Asia Pacific Viewpoint no. 50 (1):74-87. 
Leach, Colin Wayne, and Heather J. Smith. 2006. "By Whose Standard: The Affective Implications of Ethnic Minorities' Comparisons to Ethnic Minority and Majority Referents." European Journal of Social Psychology no. 36:747-60.

Lichbach, Mark Irving. 1989. "An Evaluation of 'Does Economic Inequality Breed Political Conflict?' Studies." World Politics no. 41 (4):431-70.

Major, Brenda, and Blythe Forcey. 1985. "Social Comparisons and Pay Evaluations: Preferences for Same-Sex and Same-Job Wage Comparisons." Journal of Experimental Social Psychology no. 21:393-405.

Masters, John C., and William P. Smith. 1987. Social comparison, social justice, and relative deprivation : theoretical, empirical, and policy perspectives. Hillsdale, N.J.: L. Erlbaum Associates.

McAdam, Doug, Sidney Tarrow, and Charles Tilly. 2001. Dynamics of Contention. Cambridge, and New York: Cambridge University Press

McCargo, Duncan. 2008. Tearing Apart the Land: Islam and Legitimacy in Southern Thailand. Ithaca, NY: Cornell University Press.

Meisel, C. Julius, and Carol Joyce Blumberg. 1990. "The Social Comparison Choices of Elementary and Secondary School Students: The Influence of Gender, Race, and Friendship." Contemporary Educational Psychology no. 15:170-82.

Miller, Dale T., William Turnball, and Cathy McFarland. 1988. "Particularistic and Universalistic Evaluation in the Social Comparison Process." Journal of Personality and Social Psychology no. 55:908-17.

Millward, James A. 2004. Violent Separatism in Xinjiang: A Critical Assessment. Washington, DC: East-West Center Washington.

Minorities at Risk Project. 2009. "Minorities at Risk Dataset." College Park, MD: Center for International Development and Conflict Management. Retrieved from http://www.cidcm.umd.edu/mar/.

Montalvo, Jose G., and Marta Reynal-Querol. 2005. "Ethnic Polarization, Potential Conflict, and Civil Wars." The American Economic Review no. 95 (3):796-816.

Nordhaus, William, Azam, Qazi, Corderi, David, Hood, Kyle, Victor, Nadejda Makarova, Mohammed, Mukhtar, Miltner, Alexandra, and Weiss, Jyldyz. 2006. "Detailed Description of Derivation of G-Econ Data." Yale University. Typescript. http://gecon.yale.edu/data-and-documentation-g-econ-project

Østby, Gudrun. 2008. "Polarization, Horizontal Inequalities and Violent Civil Conflict." Journal of Peace Research no. 45 (2):143-62.

Østby, Gudrun, Ragnhild Nordås, and Jan Ketil Rød. 2009. "Regional Inequalities and Civil Conflict in Sub-Saharan Africa." International Studies Quarterly no. 53 (2):301-24.

Roberts, Sean R. 2004. "A "Land of Borderlands": Implications of Xinjiang's Transborder Interactions." In Xinjiang: China's Muslim Borderland, edited by S Frederick Starr. Armonk, NY and London, England: M.E. Sharpe.

Rogowski, Ronald. 1985. "Causes and Varieties of Nationalism." In New Nationalisms of the Developed West: Toward Explanation, edited by Edward A. Tiryakian, and Ronald Rogowski. Boston: Allen \& Unwin.

Russett, Bruce M. 1964. "Inequality and Instability: The Relation of Land Tenure to Politics." World Politics no. 16 (3):442-54. 
Saideman, Stephen M. 2001. The Ties That Divide: Ethnic Politics, Foreign Policy and International Conflict. New York: Columbia University Press.

Saideman, Stephen M. . 1997. "Explaining the International Relations of Secessionist Conflicts: Vulnerability versus Ethnic Ties." International Organization no. 51 (4):721-53.

Saideman, Stephen M., and R. William Ayres. 2000. "Determining the Causes of Irredentism: Logit Analyses of Minorities at Risk Data from the 1980s and 1990s." The Journal of Politics no. 62 (4):1126-1144.

Sambanis, Nicholas. 2005. "Conclusion: Using Case Studies to Refine and Expand the Theory of Civil War." In Understanding Civil War: Evidence and Analysis, edited by Paul Collier, and Nicholas Sambanis, 299-330. Washington, DC: World Bank.

Stapel, Diederik A., and Hart Blanton. 2006. Social comparison theories : key readings, Key readings in social psychology. New York: Psychology Press.

Stewart, Frances. 2000. "The Root Causes of Humanitarian Emergencies." In War, Hunger, and Displacement: The Origins of Humanitarian Emergencies edited by E. Wayne Nafziger, Frances Stewart, and Raimo Väyrynen, 1-41. Oxford: Oxford University Press. 2002. Horizontal Inequalities: A Neglected Dimension of Development. Vol. 5, WIDER Annual Lectures. Helsinki: UNU World Institute for Development Economics Research.

- 2008. Horizontal Inequalities and Conflict: Understanding Group Violence in Multiethnic Societies. New York: Palgrave Macmillan.

Suls, Jerry M., and Richard L. Miller. 1977. Social comparison processes : theoretical and empirical perspectives. Washington \& New York: Hemisphere Pub. Corp.

Suls, Jerry M., and Ladd Wheeler. 2000. Handbook of social comparison : theory and research, Plenum series in social/clinical psychology. New York: Kluwer Academic/Plenum Publishers.

Suls, Jerry M., and Thomas Ashby Wills. 1991. Social comparison : contemporary theory and research. Hillsdale, N.J.: L. Erlbaum Associates.

Tesser, Abraham. 1988. "Toward A Self-Evaluation Maintenance Model of Social Behavior." In Advances in Experimental Social Psychology, edited by L. Berkowitz. New York: Academic Press.

Toft, Monica D. 2002. "Indivisible Territory, Geographic Concentration, and Ethnic War." Security Studies no. 12 (2):82-119.

- 2003. The Geography of Ethnic Violence: Identity, Interests, and the Indivisibility of Territory. Princeton, NJ: Princeton University Press.

Van Houten, Pieter. 1998. "The Role of a Minority's Reference State in Ethnic Relations." Archives europeenes de sociologie (European Journal of Sociology) no. 34 (Spring):110-146.

Weiner, Myron. 1971. "The Macedonian Syndrome: An Historical Model of International Relations and Political Development." World Politics no. 23 (4):665-83.

Wimmer, Andreas, Lars-Erik Cederman, and Brian Min. 2009. "Ethnic Politics and Armed Conflict: A Configurational Analysis of a New Global Data Set." American Sociological Review no. 74 (2):316-37. 
Julian Wucherpfennig, Nils B. Weidmann, Lars-Erik Cederman, Luc Girardin, Philippe Duhart, Gustav Brown, James Flora, Andreas Wimmer. 2010. "GeoEPR Dataset." http://hdl.handle.net/1902.1/14206 V2 [Version].

Wucherpfenning, Julian, Nils B. Weidmann, Luc Girardin, Lars-Erik Cederman, and Andreas Wimmer. 2011. "Politically Relevant Ethnic Groups across Space and Time: Introducing the GeoEPR Dataset." Conflict Management and Peace Science no. 28 (5):423-37.

Zagefka, Hanna, and Rupert Brown. 2005. "Comparisons and Perceived Deprivation in Ethnic Minority Settings." Personality and Social Psychology Bulletin no. 31 (4):467-82. 